Огляди літератури, оригінальні дослідження, погляд на проблему

уДК 616.36-091.8-02:616.36-002.2-099-06:618.17-053.8]-092.9

DOI 10.11603/1811-2471.2016.v0.i4.7080

\title{
МОРФОЛОГІЧНІ ЗМІНИ В ПЕЧІНЦІ СТАТЕВОЗРІЛИХ САМОК БІЛИХ ЩУРІВ ЗА УМОВ ЕКСПЕРИМЕНТАЛЬНОГО ХРОНІЧНОГО ТОКСИЧНОГО ГЕПАТИТУ ТА ЇХ ВПЛИВ НА РЕПРОДУКЦІЮ
}

\author{
ФЛ. Є. Лимар, Н. А. Лимар \\ ДВНЗ «Тернопільський державний медичний університет імені І. Я. Горбачевського МОЗ України» \\ КЗ ТОР ТОКПЦ «Мати і дитина»
}

\begin{abstract}
РЕЗЮМЕ. Погіршення демографічної ситуації в Україні впродовж минулих десятиліть продовжується. Тому збереження репродуктивного здоров'я нації $\epsilon$ пріоритетним завданням охорони здоров'я та розвитку медичної науки нашої країни. Вагомою причиною негативного демографічного показника є високий рівень безпліддя, зокрема ендокринного ґенезу, який складає 15-25 \% [1]. Порушення функції репродуктивної системи є актуальною проблемою, оскільки призводить не лише до втрати працездатності, а й до зниження репродукції людини. Значна роль у виникненні ендокринного безпліддя належить не лише генетично детермінованим змінам в організмі жінки, але й супутній патології. У жінок часто спостерігається поєднання порушень функції репродуктивної системи з хронічними гепатитами різного ґенезу. Це спонукало нас до виконання експериментальної роботи для детального вивчення та аналізу вказаної проблеми. В доступних для огляду літературних джерелах ми не знайшли подібних експериментальних досліджень щодо моделювання патологічного процесу та вивчення структурних змін у печінці та органах репродуктивної системи при хронічних гепатитах.

Ми змоделювали хронічний токсичний гепатит у статевозрілих самок білих щурів, вивчали результати клінічних, гістологічних досліджень, показники імунного та гормонального статусу, функції печінки у піддослідних тварин, а також їх репродуктивну функцію за умов експериментального токсичного гепатиту. Обстежено 40 статевозрілих самок білих щурів зі змодельованим хронічним токсичним гепатитом (ХТГ). Вивчено клінічні прояви захворювання, стан функції печінки, гормональний статус, морфологічні зміни в печінці цих тварин та їх репродуктивну функцію.
\end{abstract}

КЛЮчОВІ СЛОВА: морфологічні зміни, печінка, хронічний токсичний гепатит, репродуктивна функція.

Вступ. Зростання захворюваності репродуктивної системи продовжує викликати тривогу науковців світу. Незважаючи на вагомі наукові досягнення у діагностиці та лікуванні вказаної патології, проблема порушення функції репродуктивної системи у жінок залишається актуальною, оскільки призводить не лише до втрати працездатності, а й до зниження репродуктивної функції. У жінок часто виявляють поєднання порушень функції репродуктивної системи з хронічними гепатитами різного ґенезу [1-3]. Для детального вивчення і аналізу вказаної проблеми, виявлення змін, які впливають на патогенез захворювання, ми провели експериментальне дослідження. Вивчали результати клінічних, біохімічних та морфологічних досліджень у піддослідних статевозрілих самок білих щурів, а також їх репродуктивну функцію за умов експериментального токсичного гепатиту. Було обстежено 40 самок білих щурів репродуктивного віку, яким змодельовано хронічний токсичний гепатит (ХТГ). Метою нашого дослідження було вивчення стану печінки на тлі хронічного токсичного тетрахлорметанового гепатиту у статевозрілих самок білих щурів, а також дослідження репродуктивної функції у піддослідних тварин [4-8].

Матеріал і методи дослідження. Експериментальна частина роботи полягала у моделюванні хронічного токсичного гепатиту. Моделлю токсичного ураження тварин служила інтоксикація тетрахлорметаном ( $\left.\mathrm{CC}_{4}\right)$. Тетрахлорметан вводили через день внутрішньошлунково у вигляді $50 \%$ олійного розчину в дозі 2 г/кг маси тіла тварини. Виведення тварин з експерименту проводили в умовах знеболювання тіопентал-натрі$\epsilon м$. Проводили забір крові для біохімічних, імунологічних, гормональних досліджень та видалення гіпофіза, яєчників, матки та печінки для морфологічного дослідження. Обстежено 40 статевозрілих самок білих щурів. До 1 групи увійшли 20 самок, яким після завершення експерименту оцінювали клінічні прояви гепатиту та патоморфологічні зміни в гіпофізі. До 2 групи увійшли 15 статевозрілих самок білих щурів, яким проводили дослідження репродуктивної функції на тлі хронічного токсичного гепатиту. Контрольну групу склали 5 здорових статевозрілих самок білих щурів. У піддослідних тварин 1 та контрольної груп вивчали морфологічні зміни в печінці [4-11]. Патоморфологічне дослідження печінки виконано в навчально-науковому інституті морфології ДВНЗ «Тернопільський державний медичний університет імені І. Я. Горбачевського МОЗ України».

Результати й обговорення. Вивчені результати біохімічних показників функції печінки та морфологічних змін у печінці. У досліджуваних групах середній вік самок білих щурів склав від 6 до 8 місяців, у контрольній - 6 місяців. Маса піддо- 
Огляди літератури, оригінальні дослідження, погляд на проблему

слідних тварин в експериментальних та контрольній групах становила в середньому 190-195 грамів. Тварини дослідних груп та групи контролю були ідентичні за віком, вагою, харчуванням, умовами утримання. У піддослідних тварин 1 та 2 груп моделювали тетрахлорметановий хронічний гепатит. Для досягнення достатнього рівня відтворюваності та точності експериментальної моделі взято до уваги астральний цикл піддослідних тварин. Оскільки морфологічні зміни в органах настають не відразу, дослідження проводили через 1 місяць після моделювання експериментального токсичного гепатиту. Спостерігали за поведінкою тварин, їх руховою активністю, функцією травного тракту. Виявлені клінічні прояви хронічного токсичного гепатиту опубліковані в попередніх наукових статтях. Визначені показники підтверджують літературні дані [5-11]. Через 3 місяці в 3 піддослідній групі проводили аналіз реалізації репродуктивної функції. Виявлено, що у 9 самок $(60,0 \%)$ вагітність не наступила. Результати біохімічних показників функції печінки опубліковані в попередніх статтях.

Структура печінки контрольної тварини представлена на рисунку 1. Слід зазначити, що часточкова будова та балкова організація її збережена, центральні вени візуалізувались незначно, просвіти синусоїдів добре контуруються, вони містять поодинокі макрофаги. Портальні тракти не розширені, кровонаповнення судин портальних трактів звичайне.

У тварин, хворих на хронічний токсичний гепатит, клінічно відмічались значні зміни загального стану: агресія, яка змінювалась фізичним нездужанням. Морфологічні зміни в їх печінці представлені на рисунку 2.

Токсичне ураження печінки експериментальних тварин супроводжувалось вираженим порушенням структури печінкової часточки та дистрофічно-некротичними змінами в гепатоцитах (рис. 2).

Таким чином, на фоні токсичного ураження печінки у тварин розвиваються значні дистрофічно-некротичні зміни в гепатоцитах, які призводять до порушення білковосинтезуючої, ферментативної функції печінки, проявляються вираженими ознаками інтоксикації, чим викликають порушення астрального циклу та знижують репродуктивну функцію тварин.

Висновки. 1. При експериментальному хронічному токсичному гепатиті в печінці відбуваються

\section{ЛІТЕРАТУРА}

1. Дубоссарская 3. М. Теория и практика гинекологической эндокринологии / 3. М. Дубоссарская. - Днепропетровск, 2005. - 409 с.

2. Концепція державної цільової соціальної програми профілактики, діагностики та лікування вірусних гепатитів на період до 2016 року МОЗ України. 
Огляди літератури, оригінальні дослідження, погляд на проблему

- http:http:/aiddu.org.ua/wp-content/uploads/2014/10/ unifikovaniy-protokol-gepatiti-2014.pdf.

3. Швец Н. И. Лекарственные поражения печени, связанные с приемом антибиотиков / Н. И. Швец, Т.М. Бенца // Сучасна гастроентерологія. - 2009. - № 3. - С. 43-49.

4. Загальні етичні принципи експериментів на тваринах. Перший національний конгрес з біоетики, Київ, 2001 р. // Ендокринологія. - 2003. - Т. 8, № 1. - С. 142-145.

5. Голубєва М. Г. Лікувальний вплив амізону на перебіг експериментального алкогольно-тетрахлорметанового гепатиту / М. Г. Голубєва // Ліки. - 2003. № 5-6. - С. 71-73.

6. Рикало Н. А. Експериментальна модель хронічного тетрахлорметанового гепатиту та цирозу печінки у нестатевозрілих щурів / Н. А. Рикало // Вісник Української медичної стоматологічної академії. - 2009. - Т. 9, № 2. - C.116-118.

7. Вивчення ліпотропної дії поліфенольних екстрактів з насіння винограду на моделі гострого тетрах- лорметанового гепатиту / А. Л. Загайко, С. В. Заїка, О. А. Красільнікова, І. В. Сенюк. // Укр. біофармацевтичний журнал. - 2012. - № 1-2 (18-19). - С. 46-49.

8. Рикало Н. А. Експериментальна модель хронічного медикаментозного гепатиту у статевозрілих щурів / Н. А. Рикало, О. Ю. Гумінська, О. В. Андрощук // Таврический медико-биологический вестник. - 2012. T. 15, № 3, ч. 1 (59). - С. 283-286.

9. Protective effects of caffeic acid phenethyl ester (CAPE) on carbon tetrachloride-induced hepatotoxicity in rats / I. Kus, N. Colakoglu, H. Pekemez [et al.] // Acta Histochem. - 2004. - No106 (4). - P. 289-297.

10. Neoptolemos J. P. Fast fact: Diseases of the pancreas and biliary tract / J. P. Neoptolemos, M. S. Bhutani // Oxford: Health Press, 2006. - P.112-117.

11. Bhadauria M. Multiple treatment of propolis extract ameliorates carbon tetrachloride induced liver injury in rats / M. Bhadauria, S. K. Nirala, S. Shukla // Food. Chem. Toxicol. - 2008. - Vol. 46 (8). - P. 2703-2712.

\title{
MORPHOLOGICAL CHANGES IN THE LIVER OF MATURE FEMALE WHITE RATS UNDER THE EXPERIMENTAL CHRONIC TOXIC HEPATITIS AND THEIR IMPACT ON REPRODUCTION
}

\author{
@L. Ye. Lymar, N. A. Lymar \\ I. Horbachevsky Ternopil State Medical University \\ Ternopil Regional Municipal Perinatal Centre «Mother and Child»
}

SUMMARY. The worsening of demographic situation in Ukraine over the past decades continues. Therefore, the reproductive health of the nation in Ukraine is a priority of health and medical science. A significant reason for the negative demographic indicator is the high level of infertility, including endocrine genesis, is 15-25\% [1]. Impaired function of the reproductive system is an urgent problem because not only lead to loss of efficiency, but also reduce human reproduction. A significant role in causing of endocrine infertility includes not only genetically determined changes in women, but comorbidity. Women have often a combination of reproductive system dysfunction with chronic hepatitis of different genesis. This prompted us to perform experimental work for a detailed study and analysis of this problem. In the foreseeable literature we found no such experimental studies on pathological process modeling and study of the structural changes in the liver and reproductive organs in chronic hepatitis. We modeled chronic toxic hepatitis in mature female white rats. We studied the results of the clinical, histological studies, indicators of immune and hormonal status, liver function in experimental animals and their reproductive function under the experimental toxic hepatitis. The study involved 40 sexually mature females of white rats that simulated chronic toxic hepatitis (CTH). We studied the clinical manifestations of the disease, the condition of liver function, hormonal status, morphological changes in the liver of these animals and their reproductive function.

KEY WORDS: morphological changes of the liver, chronic toxic hepatitis, reproductive function.

Отримано 28.07.2016 